\title{
Investigation of Water Permeability of Ultrasonic Seaming on PU Coated Fabrics
}

\author{
PU Kaplamalı Kumaşlarda Ultrasonik Dikişin Su Geçirgenliğinin Araştırılması
}

\author{
Ayşe ŞEVKAN MACIT ${ }^{1}$ (D), Bahar TIBBER ${ }^{1}$ \\ ${ }^{1}$ Uşak University, Engineering Faculty, Textile Engineering Department, 1 Eylül Kampüsü, Uşak, Türkiye
}

\begin{abstract}
Technical textiles take an important place in textile and apparel sector. In technical textiles, ultrasonic seaming method besides conventional seaming methods is one of the alternative methods used in seaming processes of functional textiles. In this study, the effects of ultrasonic seaming method in which needle and thread usage is not needed on waterproofing property of PU coated fabrics in comparison with conventional seaming methods were investigated. Sewn fabrics obtained with different seaming parameters were exposed to washing process and the waterproofing properties of these fabrics were tested considering before and after washing processes. The results evaluated in terms of seam type, fabric type, ultrasonic seaming velocity and washing process were statistically analyzed. According to the test results, waterproofing properties of ultrasonically sewn fabrics are higher than that of conventionally sewn fabrics. The difference between waterproofing values of ultrasonically and conventionally sewn fabrics are found to be statistically significant. It is determined that waterproofing property of the fabrics are in relation with the other parameters.
\end{abstract}

Keywords: Ultrasonic seam, water permeability, coated fabric

Öz

Teknik tekstiller, tekstil ve konfeksiyon sektöründe önemli bir yer tutmaktadır. Teknik tekstillerde, konvansiyonel dikiş yöntemlerinin yanı sıra ultrasonik dikiş yöntemi, fonksiyonel tekstillerin dikiş işlemlerinde kullanılan alternatif yöntemlerden biridir. Bu çalışmada, iğne ve iplik kullanımının gerekmediği ultrasonik dikiş yönteminin PU kaplamalı kumaşların su geçirmezlik özelliği üzerindeki etkileri konvansiyonel dikiş yöntemleri ile karşılaştırmalı olarak incelenmiştir. Farklı dikiş parametreleri ile elde edilen dikilmiş kumaşlar yıkama işlemine tabi tutulmuş ve bu kumaşların su geçirmezlik özellikleri yıkama işlemlerinden önce ve yıkama işlemlerinden sonra test edilmiştir. Dikiş tipi, kumaş tipi, ultrasonik dikiş hızı ve yıkama işlemi açısından değerlendirilen sonuçlar istatistiksel olarak analiz edilmiştir. Test sonuçlarına göre, ultrasonik olarak dikilmiş kumaşların su geçirmezlik özellikleri, konvansiyonel olarak dikilmiş kumaşlardan daha yüksektir. Ultrasonik dikişle dikilmiş kumaşlar ile konvansiyonel olarak dikilmiş kumaşların su geçirmezlik değerleri arasındaki fark istatistiksel olarak anlamlı bulunmuştur. Kumaşların su geçirmezlik özelliğinin diğer parametrelerle ilişkili olduğu belirlenmiştir.

Anahtar Kelimeler: Ultrasonik dikiş, su geçirgenliği, kaplama kumaş

\section{I.INTRODUCTION}

Apparel industry has a great importance on obtaining different products used in textile sector. Various seaming methods are used in conversion of different fabrics into final product. However, seaming process of some types of textile products which requires functional specifications is in need of alternative seaming methods besides conventional seaming methods. One of these alternative methods is ultrasonic seaming which has taken attention from researchers in recent years.

Ultrasonic seaming method is not only an energy saving method, but also it can perform sewing process without the need for the materials such as needle and thread that have been used in the conventional seaming methods. Holes occurring because of the needle usage in conventional seaming can be determined as an undesirable result which is considered as disadvantage 
in a waterproof garment. Therefore the importance of ultrasonic seaming method in which no needle and thread are needed can be comprehensively recognized. By using ultrasonic seaming method, it can be possible to obtain seams with high waterproofing properties. Also recycling of fabrics seamed with ultrasonic seaming method is easier. Ultrasonic seaming is used in a wide range of industries such as technical textiles, medical, filtration and automotive [1]

The waterproofing property of the ultrasonic seaming method is rarely studied in literature. [9] compared ultrasonic seaming method and conventional seaming method in their study in which they investigated various properties of ultrasonic seaming by using woven fabrics. According to the results of the study, waterproofing property of ultrasonic seam is found to be higher than that of conventional seam. [5] studied ultrasonic seaming method in comparison with conventional seaming method on nonwoven surgical gowns and they reported that there is no water penetration in the surgical gowns sewn by using ultrasonic seaming method. On the other hand they observed water penetration in the surgical gowns sewn by using conventional seaming method due to the needle holes in the fabric and this situation which can be considered as hazardous for health. [7] studied the properties including waterproofing property of ultrasonic seaming method and conventional seaming method on the fabrics used in inner faces of sport shoes. When waterproofing property is taken in hand, it is observed that ultrasonic seam damaged the structure and demonstrated no waterproofing. Studies investigating the tensile properties of ultrasonic seaming are frequently available in literature in recent years and in general it is stated that seam strength of ultrasonic seaming is lower than the conventional seaming $[3,6,5]$. Also there is a study stating that seam strength of ultrasonic seam is higher than that of conventional seam
[1]. Hence, when determining intended usage areas, it should be taken into account that waterproofing properties of these ultrasonically sewn fabrics can be advantageous with satisfying strength values considering the appropriate products.

Our study aims to compare ultrasonic seaming method and conventional seaming method in terms of water permeability by using woven fabrics coated with polyurethane membrane which are used as blouson. Nine types of sewn fabrics were gained by changing the production speed of ultrasonic seam. Water permeability property of the sewn fabrics was compared in terms of seam type, fabric type, ultrasonic seaming velocity and washing process.

\section{II.EXPERIMENTAL SET-UP AND PROCEDURE}

In our study, woven fabrics coated with polyurethane membrane were used to compare water permeability property. The fabrics were sewn with ultrasonic seam and conventional seam by using different parameters. The properties of fabrics and the seam parameters are characterized in Table 1.

Fabric samples were prepared according to the test standard along the warp directions. Ultrasonic seam process was applied by using Pfaff 8310 ultrasonic sewing machine. Amplitude of the machine was $100 \%$ during the sewing process. Two different speeds were performed as $25 \mathrm{dm} / \mathrm{min}$ (v1) and $45 \mathrm{dm} / \mathrm{min}$ (v2). A roller was used that has $8 \mathrm{~mm}$ width (Figure 1). Conventional seam process was performed to woven fabrics by using Brother S-7200C-403 electronic lock stitch sewing machine. Stitch density was 2.6 stitches/ $\mathrm{cm}$.

Table 1. Properties of the fabrics and seam parameters.

\begin{tabular}{|c|c|c|c|c|c|c|c|}
\hline Fabric code & $\begin{array}{c}\text { W e a v i n g } \\
\text { structure }\end{array}$ & $\begin{array}{c}\text { Weight in grams } \\
\left(\mathbf{g} / \mathbf{m}^{2}\right)\end{array}$ & Thickness $(\mathbf{m m})$ & Raw material & $\begin{array}{c}\text { Sewn fabric } \\
\text { code }\end{array}$ & Seam type & Velocity code \\
\hline $\mathrm{F}_{1}$ & Plain & 105 & 0.366 & Polyester & $\mathrm{F}_{1} \mathrm{v}_{1}$ & Ultrasonic seam & $\mathrm{v}_{1}$ \\
\hline $\mathrm{F}_{1}$ & Plain & 105 & 0.366 & Polyester & $\mathrm{F}_{1} \mathrm{v}_{2}$ & Ultrasonic seam & $\mathrm{v}_{2}$ \\
\hline $\mathrm{F}_{2}$ & Plain & 170 & 0.432 & Polyester & $\mathrm{F}_{2} \mathrm{v}_{1}$ & Ultrasonic seam & $\mathrm{v}_{1}$ \\
\hline $\mathrm{F}_{2}$ & Plain & 170 & 0.432 & Polyester & $\mathrm{F}_{2} \mathrm{v}_{2}$ & Ultrasonic seam & $\mathrm{v}_{2}$ \\
\hline $\mathrm{F}_{3}$ & Twill & 170 & 0.540 & Polyester & $\mathrm{F}_{3} \mathrm{v}_{1}$ & Ultrasonic seam & Ultrasonic seam \\
\hline $\mathrm{F}_{3}$ & Twill & 170 & 0.540 & Polyester & $\mathrm{F}_{3} \mathrm{v}_{2}$ & $\mathrm{v}_{2}$ \\
\hline $\mathrm{F}_{1}$ & Plain & 105 & 0.366 & Polyester & $\mathrm{F}_{1} \mathrm{~L}$ & Conventional seam & Lock stitch \\
\hline $\mathrm{F}_{2}$ & Plain & 170 & 0.432 & Polyester & $\mathrm{F}_{2} \mathrm{~L}$ & Conventional seam & Lock stitch \\
\hline $\mathrm{F}_{3}$ & Twill & 170 & 0.540 & Polyester & $\mathrm{F}_{3} \mathrm{~L}$ & Conventional seam & Lock stitch \\
\hline
\end{tabular}




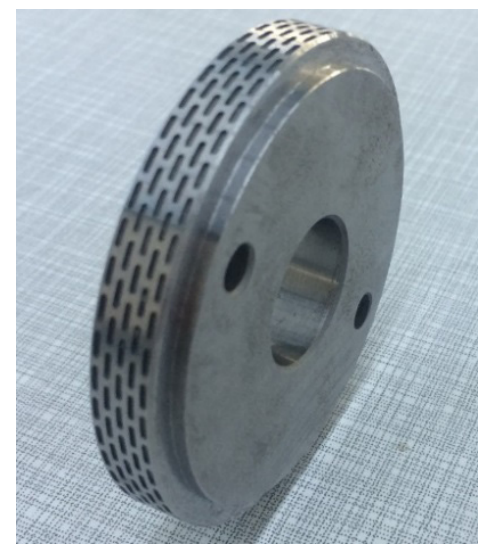

Figure 1. The roller used in the study.

All of the sewn fabrics were washed at $30^{\circ} \mathrm{C}$ with synthetic washing programme without prewashing according to TS EN ISO 6330:2012 test standard. 4 g/1 ECE nonphosphate reference detergent without optical brightening agent was used for washing processes. Washing process was repeated for five times.

\section{III.ANALYSIS}

Waterproofing property can be defined as the ability of the fabric to protect from water and rain (Bulut and Sülar, 2008). This property can be tested either by laboratory tests or by wear trials [4]. In this study, waterproofing property of the sewn fabrics were evaluated through laboratory test analyses. Five samples were prepared from each sewn fabric. The samples were conditioned for 24 hours in standard atmospheric conditions (temperature $20 \pm 2 \mathrm{oC}$ and relative humidity $65 \pm 2 \%$ ) before testing. The water permeability tests were performed to fabrics before and after washing processes with Prowhite Hydrostatic Head Tester according to TS 257 EN 20811:1996. As the waterproofing of the fabric increases, the hydrostatic pressure also increases in the water permeability test and thus higher waterproofing values are obtained. Test results were evaluated considering fabric type, seam type, ultrasonic seaming velocity and washing process. To evaluate the importance of test results, SPSS 13.0 programme was used with the analysis of variance (ANOVA). In this way the effects of fabric type, seam type, ultrasonic seaming velocity and washing process on waterproofing property were analyzed.

\section{IV.RESULTS AND DISCUSSIONS}

Water permeability test results of the ultrasonically and conventionally sewn fabrics before and after washing processes were given in Table 2 and Table 3, respectively.
Table 2. Water permeability test results of ultrasonically sewn fabrics before and after washing processes ( $\mathrm{cm} \mathrm{wg}$ ).

\begin{tabular}{|c|c|c|c|c|}
\hline \multirow{2}{*}{ Fabric code } & \multicolumn{2}{|c|}{ Before washing } & \multicolumn{2}{c|}{ After washing } \\
\cline { 2 - 5 } & V1 & V2 & V1 & V2 \\
\hline F1 & 59 & 56 & 24 & 5 \\
\hline F2 & 131 & 96 & 17 & 7 \\
\hline F3 & 96 & 84 & 23 & 15 \\
\hline
\end{tabular}

Table 3. Water permeability test results of conventionally sewn fabrics before and after washing processes ( $\mathrm{cm} \mathrm{wg}$ ).

\begin{tabular}{|c|c|c|}
\hline \multirow{2}{*}{ Fabric code } & \multicolumn{2}{|c|}{ Conventional seam } \\
\cline { 2 - 3 } & Before washing & After washing \\
\hline F1 & 13 & 6 \\
\hline F2 & 15 & 8 \\
\hline F3 & 15 & 6 \\
\hline
\end{tabular}

When Table 2 and Table 3 are examined; test results demonstrated that waterproofing values of the fabrics sewn with ultrasonic seam are higher than that of conventional seam. In Figure 2, water permeability test results of ultrasonically and conventionally sewn fabrics are presented together before and after washing processes. In ultrasonic seam, no holes are occurred during the seaming process and this case declares that waterproofing property of the fabrics sewn using this method is higher than that of conventionally sewn ones. In ultrasonic seam process, these values decreased with the increase of seaming velocity. It is expected because at lower velocities, fabric layers weld much better due to much more ultrasonic energy exposure and by this way waterproofing property of the fabric improves. In addition, waterproofing values decreased after washing processes for both ultrasonic and conventional seams. This can be result from the damage that the washing process causes in ultrasonic seam. In conventional seam, coating of the fabric around the stitch areas might be damaged during washing processes. Therefore waterproofing values may decrease after washing processes for both methods.

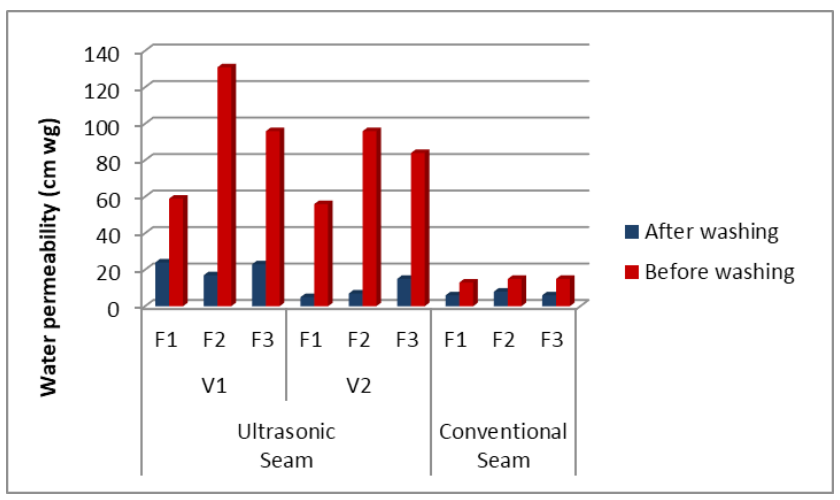

Figure 2. Water permeability test results of ultrasonically and conventionally sewn fabrics before and after washing processes. 
It is clear from the results that the lowest waterproofing values were observed in the fabric with the lowest weight in grams before washing process. This can be related to the lower weight in grams and lower thickness values of the fabric. On the other hand, waterproofing values are higher in plain structure than in twill structure at equivalent weight in grams before washing process in ultrasonic seam. The difference between plain and twill structure considering the values of ultrasonically sewn samples before washing process is found statistically significant (Sig. $<0,05$ ). This result in a close relation with the number of intersection points for warp and weft yarns in plain woven fabrics which are higher than that of in twill structure. But no generalization can be made for the results after washing process in terms of fabric type. According to statistical analyzing of fabric differences considering the all values for both ultrasonic and conventional seam types before and after washing processes, the differences of waterproofing values between fabrics are statistically insignificant.

Table 4. The analysis of variance table for water permeability test results of the sewn fabrics.

\begin{tabular}{|c|c|c|}
\hline Factor & F & Significance \\
\hline Washing process & 50,275 &, $000^{*}$ \\
\hline Seam type & 27,578 &, $000^{*}$ \\
\hline Fabric type & 2,526 &, 086 \\
\hline Seaming velocity &, 990 &, 324 \\
\hline
\end{tabular}

*: Statistically significant for $\alpha=0.05$

The effects of washing process, seam type are found statistically significant on water permeability as seen in Table 4. On the other hand, the effects of fabric type and seaming velocity are found statistically insignificant on water permeability (Table 4).

\section{V.CONCLUSION}

In this study, ultrasonic and conventional seaming were performed to polyester woven fabrics coated with polyurethane membrane which are used as blouson. The effect of ultrasonic seaming parameters and fabric structure on water permeability were investigated before and after washing processes. The following states can be concluded throughout this study:

Our study demonstrated that waterproofing values of the ultrasonic seam are higher than the conventional seam before and after washing processes. The difference between waterproofing performances of ultrasonic seaming method and conventional seaming method are found to be statistically significant.
In ultrasonically seamed samples, waterproofing values decreased with the increase of seaming velocity. When the values are statistically investigated, difference between them can be stated as insignificant.

Besides, among all of the fabrics the lowest waterproofing value before and after washing processes is obtained from the lightest fabric coded F1. For ultrasonic seaming method, higher waterproofing values in plain woven fabric than that of twill structure are observed at the equilavent weight in grams before washing $(\mathrm{F} 2>\mathrm{F} 3)$ and this result is found statistically significant (Sig.<0,05). But the difference between the fabrics considering the all values for both ultrasonic and conventional seam types before and after washing processes are found statistically insignificant.

In addition, after washing process waterproofing values decreased for all types of fabrics sewn by both of the methods. Moreover, the difference between waterproofing values before and after washing processes has statistical significance.

Ultrasonic seaming takes place in various sectors as an advantageous seaming method in terms of both ease of use, fast seaming process, not needing production materials such as needle or thread and waterproofing property. From an aspect of suitable end uses for ultrasonic seaming method, it is thought that the ultrasonic seaming method may find more uses where waterproofing property is needed either by the enhancement of physical properties of seams by changing parameters or where the high physical performances are not expected from the product.

\section{Acknowledgments}

This study has been supported by Uşak University Scientific Research Project under grant [2015/MF005]. I would like to thank to Prof. Dr. M. Çetin Erdoğan and Dr. Serkan Boz at the Textile Engineering Department in Ege University for using ultrasonic sewing machine.

\section{References}

[1] Boz S., Erdoğan M. Ç. (2011). Ultrasonic energy usage in apparel industry. Tekstil ve Konfeksiyon, 21, 91-96.

[2] Boles, K. (2012). Ultrasonic Examination of Alternative Fabric Joining Techniques Compared to Traditional Sewing. Mc Nair Scholars Research Journal, 5(1), Article 3.

[3] Appleby, C. K. (2009). Development of Fabric Seaming For Clothing Using Ultrasonic Sealing Technique. Senior Honors Thesis, Eastern Michigan University, Michigan. 
[4] Bulut, Y., Sülar, V. (2008). Kaplama veya Laminasyon Teknikleri ile Üretilen Kumaşların Genel Özellikleri ve Performans Testleri. Tekstil ve Mühendis, 15(70-71), 5-16.

[5] Eryürük, S. H., Karagüzel Kayaoglu, B., Kalaoglu, F. (2017). A study on ultrasonic welding of nonwovens used for surgical gowns. International Journal of Clothing Science and Technology, 29(4), 539-552.

[6] Ghosh, S., Reddy, R. K. (2009). Ultrasonic Sealing of Polyester and Spectra Fabrics Using Thermo Plastic Properties. Journal of Applied Polymer Science, 113, 1082-1089.

[7] Jevšnik, S., Eryürük, S. H., Kalaoğlu, F., Karagüzel Kayaoğlu, B., Komarkova, P., Golombikova, V., Stjepanovič, Z. (2017). Seam properties of ultrasonic welded multilayered textile materials. Journal of Industrial Textiles, 46(5), 11931211.

[8] Porav V. (2013). Unconventional assambly. Annals of the University of Oradea, Fascicle of Textiles, 14, 85-88.

[9] Shi, H., Wang, J., Chen, X., Luo, S., Zhang, L. (2016). Research on the seam performance of waterproof clothing based on continuous ultrasonic welding technology. International Journal of Clothing Science and Technology, 28(2), 171-190.

[10] TS EN ISO 6330:2012. Textiles - Domestic washing and drying procedures for textile testing.

[11] TS 257 EN 20811:1996. Textiles Fabrics-Determination of Resistance to Water Penetration-Hydrostatic Pressure Test. 